\title{
Cretaceous Geology, Age-Differences and Economic Geology of Gidan Alfarma Environ, Northwestern Nigeria
}

\author{
I.A. Kankara ${ }^{* 1}$, T. Adagba $^{2}$, A. Yunusa ${ }^{3}$ \\ ${ }^{1}$ Senior Researcher/Senior Lecturer, Dept. of Geology, Federal University Dutsin-Ma, Katsina, Nigeria \\ Email id: aibrahim@fudutsinma.edu.ng \\ ${ }^{2}$ PG Research Student/Lecturer II, Dept. of Civil Engineering, Federal University Dutsin-Ma, Katsina, Nigeria \\ ${ }^{3}$ PG Research Student, Dept. of Geology, Ahmadu Bello University Zaria, Kaduna, Nigeria
}

\begin{abstract}
In this present study, the geology and economic aspect of lithological units of Sokoto Basin, sheet 4 South West Sokoto, part of Nigerian Sedimentary Basins were studied. It is bounded by latitudes N 13 36 30"- N $13^{\circ} 40^{\prime} 45^{\prime \prime}$ and longitudes E $05^{\circ} 38^{\prime} 00^{\prime \prime}-\mathrm{E} 05^{\circ} 40^{\prime} 44^{\prime \prime}$ to gently undulating plain which was mapped on the scale of 1:25,000. The methodology adopted was mainly primary data which involved reconnaissance survey and actual or full field survey. The economic deposits include clays/ shale, lateritic ironstones, limestone, phosphate and gypsum, which are mined by the local artisanal miners.
\end{abstract}

Keywords - Cretaceous Geology; Age-determination; Economic Geology; Sokoto Basin; Northwestern Nigeria.

\section{Introduction}

The study area is located in the southeastern part of the Iullemeden basin, locally known as Sokoto Basin. It is a northwestern sector of the Nigerian Iullemeden basin which is surrounded to the east and south by the precambrian basement complex. Within the Sokoto basin, there is no outcrop of basement complex. Rather it is covered by series of sedimentary rocks, which is laid down under varied environmental situations ranging from continental to marine events (Jones, 1948).

The sedimentary rocks in the Sokoto basin have been classified under four categories viz (Figure 1). The first category is the Gundumi Formation which is preMaastritchian and the oldest sedimentary rock in the Basin directly overlying the basement complex. It is made up of sandstone and clays, the entire continental original (Yunusa, 2018). The sandstone portion of the Formation contains a lot of water and is currently been harnessed through boreholes.

The second category is Rima Group made up of three distinct marine sediments namely Taloka, Dukamaje, and Wurno Formations. The Rima Group is Maastritchian. The Taloka Formation is the oldest in Rima Group. It consists of multiple layers of siltstones and clayey poorly consolidated. The sandstone in this formation has a lot of water. The Dukamaje Formation is shaly with some limestone and mudstone (Kankara, 2011). This Formation is non-aquiferous (Figure 1) The Wurno Formation consists of pale, fine-grained, friable sandstone. It is similar to Taloka Formation.
The third category of sedimentary rocks in Sokoto basin is referred to as Sokoto Group, which is of marine origin, also an Eocene. It consists of three main Formations, the Dange, Kalambaina and Gamba Formations (Kankara, 2011).

The Dange Formation forms the base of SokotoGroup which consist of indurated bluish-grey, interbedded shale with a thin layer of yellowish- brownish limestone. While the Kalambaina Formation which overlies the Dange shale, is made up of marine white clay-limestone and shales. The Sokoto Group also has the youngest formation known as Gamba shale. The Sokoto Group is aquiferous (Kogbe, $1973 ; 1979)$. The fourth category of sedimentary rock in the Sokoto basin is the Gwandu Formation which consists of clays and sanstones of Eocene with a high potential of groundwater (Figures 1).Minerals such as marble, gypsum, phosphate, lignite and limestone can be found in the Sokoto basin.

\section{The Study Area}

\subsection{Location, Extent and Accessibility}

The study area is located at the Gada Local Government Area of Sokoto State. It is about $130 \mathrm{~km}$ south from Sokoto city, and is found between latitudes N $13^{\circ} 36^{\prime}$ $30^{\prime \prime}-\mathrm{N} 13^{\circ} 40^{\prime} 45^{\prime \prime}$ and longitudes E 05 $38^{\prime} 00^{\prime \prime}-\mathrm{E} 05^{\circ}$ $40^{\prime}$ 44". The study area lowering a total area of approximately $40 \mathrm{~km}^{2}$ which was carried out on the scale of $1: 25000$. It is readily accessible to motor roads, footpaths, camel/donkey tracks and river channels and other accessible watercourses (Figure1). 
It has an average annual temperature of $28.4^{\circ} \mathrm{C}$ with a relatively annual rainfall of $629 \mathrm{~mm}$. The study area is sparsely populated with dispersed villages and settlements which are so scattered and are mostly indigenous of Hausa's and Fulani's. Agricultural activities abound in the mapped area. Geographically speaking, it is underlain by Kalambaina, Dange and Wurno Formations (Kankara, 2011)

\subsection{Relief and Drainage}

The study area is in a dry sahel surrounded by sandy Savannah and isolated hills. According to Köppen and Geiger, the climate is classified as bush, with an annual average temperature $28.4^{\circ} \mathrm{C}$ and rainfall of $629 \mathrm{~mm}$.

The climate of the study area is classified into tropical continental and maritime. The rainy season is from April October. Much of the rain falls in the study area between June and September. The relief of the study area is characterized as a monotony of low land interrupted by isolated flat-topped hills (mesas) and escarpments. The escarpments in the study area are found along hills and rise up to $488 \mathrm{~m}$ (Ajibade and Wright, 1998). The drainage of the study area is drained by the Rima River and its tributaries most of which rise in the southern part of the study area. The Bunsuru and Gangare rivers flow in a northerly direction joining the Rima River near Sabon Birni.

\section{Materials and Methods}

The Sokoto basin of Nigeria forms the southern sector of Iullemmeden Basin, one of the young (mesazoic tertiary) inland cratonic sedimentary basin of West Africa. The entire Sokoto Basin is believed to have developed by tectonic epeiorogenic movements or stretching and rifting of The Paleocene rocks of Kalambaina lime stones and the underlying marine shales intersected by the Illela borehole belong to the Kalambaina and Dange Formations respectively. The Illela bore is situated in the NNW part of Sokoto Basin bordering Northern Nigeria and the Niger Republic (Figure 1).

The Sokoto Basin represents the south-eastern extension of the trans-Saharan Paleocene transgression of the Tethys (Ball, 1930; Kogbe, 1981) Lithostratigraphically, the sediments from the borehole comprise the lower marine shales, the inter bedding lime stones and the upper continental intercalation of siltstones, mudstones and ironstones. Carbonate sediments are particularly sensitive to environmental changes; their sedimentation is rapid but easily inhibited (Dunbam, 1962; Greiger, 1966) Temperature variations influence biogenic activities and affects sediment production; thus most carbonate production is strongly depth-dependent.

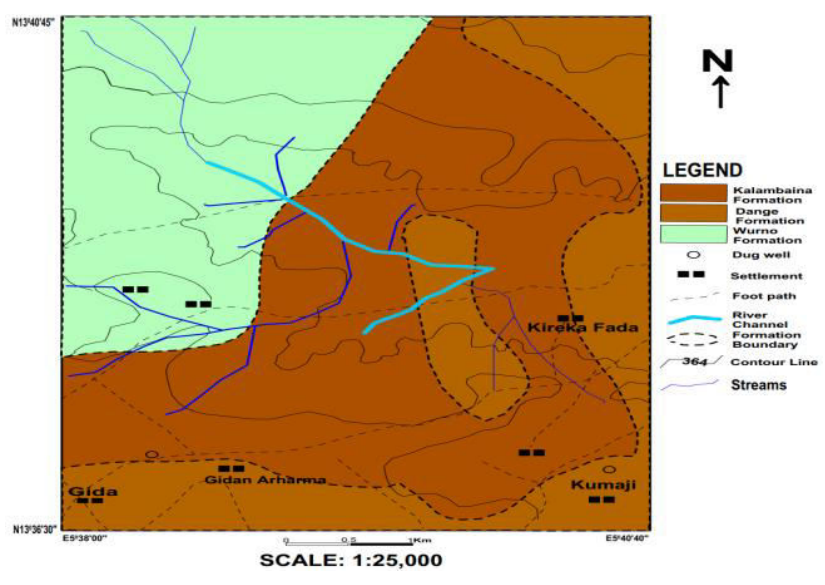

Fig. 1: Geological Map of area of study

\section{Review of Related Literature}

Kalambaina Formation is found in the north, southwest and middle of the study area (Figure 1) The Formation consist of marine, yellowish, clayey limestone and shale. The study reveals that the limestone of this area is mud supported and consists of carbonate rocks including bioclastic wackstone and algae wackstone. The carbonate rocks have been diagenetically altered to varying degrees ranging from early to late diagenesis due to the presence of sparycalcite which indicates the degree of diagenesis. Most of the outcrops of Kalambaina Formation in the study area have structures like bedding, and wavy lamination. Some of the outcrops have undergone both biological and physical weathering (Adekeye and Akende, 2004)

Wurno Formation is found in the north western part of the study area. The sediments consist of pale-colored, friable, fine-grained, sandstones, siltstone and intercalated mudstones. The loosely consolidated nature of the sediments makes them very easily susceptible to weathering. The fine-grained, loosely cemented sandstone, siltstone and mudstone of Wurno Formation in the study area have structures like load cast, bioturbation and lamination. Most of the outcrops observed in the study area were weathered (chemical and biological weathering) (McCurry, 1976; Kankara, 2011)

\section{Data Collection and Analysis}

Fieldwork exercise was carried out at places like Gidan Alharma, Kumaji, GidanGado and Kirekafada, Gada Local Government, in Sokoto State, Nigeria.

Outcrop sections were logged and described. Rock samples were as well collected and labeled. The laboratory work involved petrographic analysis of the limestone; standard thin sections were prepared for routine carbonate identification and textural description. Microfacies 
identification was carried out using a petrographic microscope with transmitted light. Microfossils specifically foraminifera, ostracod and conodont species were washed out from some of the shale samples using hydrogen peroxide $\left(\mathrm{H}_{2} \mathrm{O}_{2}\right)$ and de-ionized water. The field mapping was accompanied (Figure 2) by selected traverse and use of field equipment such as compass clinometer which was used in measuring the trends and positions, sack used as sampling bag for carrying samples, a hammer which was used in collecting samples and serves as a scale of some photographs snapped, hand lens used in magnifying mineral grains in some rocks and structures, measuring tape which was used in logging and measuring the depth of water table in dug wells, masking tape used for labeling samples locations and their coordinates, Global positioning system (GPS) was used in locating the samples site. The field mapping was carried out on a scale of 1:25000 using a planimetric extracted from Sokoto sheet, sheet $4 \mathrm{SW}$.

\section{Interpretation of Results}

\subsection{Geology of the Cenomanian-Turonian}

Hippopodium Furon is in occurrence (Jones, 1948). The Lower Turonian fauna comprises Exogyraolisiponens is sharpe, Paravascocerascauvinichudeau and Paracanthoceraschevalieri (Peters, 1976). The Upper Turonian is sandy and regressive. Cenomanian Turonian marine beds are known in boreholes in the Gao trough (Kankara, 2011) and between the Gao trough and the Adrar des Iforas (Ogezi, 1977).

\subsection{Maastrichtian Geology}

According to Dunbam (1962), the transgressive sandstone sequence found in the Niger Republic is referred to as the Cenomanian continental hamadien. It is equivalent to north-western Nigeria Taloka formation and this comprises a lower brown, carbonaceous mudstone with lignite beds, and an upper sequence of alternating thin, parallel-bedded, tabular, laterally persistent, clayey, finegrained sandstone, siltstones and massive, tabular mudstones. The lower mudstones and siltstones are crosslaminated. In exposures northeast of Sokoto, pelecypod casts and impressions, worm fecal castings and Thalasinoides occur in the middle siltstone beds.

The foraminiferamicrofaunas of the Dukamaje formation support Middle to Late Maastrichtian age (Peters, 1976). Marine Maastrichtian beds pinch-out to the northwest of Sokoto in the southeastern part of the Iullemmeden Basin. There is an exposure of marginal marine Maastrichtian beds $450 \mathrm{~km}$ south of the Sokoto area in the middle Niger valley in southern Nigeria (Adekeye and Akende, 2004), but these beds have yielded only arenaceous foraminifera of marsh and the transitional origin and belong to a contemporaneous embayment from the Gulf of Guinea which exists in southern Nigeria.

The second episode began with the maastritchian transgression when the sea moved northwards from the Gulf of Guinea through the mid-Niger Basin and southward from the Mediterranean through the Sahara. This transgression continued into the Paleocene. The Rima Group (Maastritchian) and the Sokoto Group (Paleocene) were deposited during this period.

The third and final episode began during the early Eocene with the regression of the sea. Continental conditions prevailed again and continued till the present day. The Gwandu Formation of the Eocene age was laid down during this final episode.

Table 1: Generalized Stratigraphic setting of the Sokoto Basin. Source: (Yunusa, 2018)

\begin{tabular}{|c|c|c|c|}
\hline AGE & FORMATION & GROUP & ENVIRONMENT \\
\hline QUATERNARY & Sandy drifts, laterites & & Continental \\
\hline EOCENE - MOCENE & $\begin{array}{l}\text { Gwandu Formation } \\
\text { - Unconformity }\end{array}$ & "Continental Terminal" & Continental \\
\hline UPPER PALEOCENE & $\begin{array}{l}\text { Gamba Formation } \\
\text { Kalambaina Formation } \\
\text { Dange Formation }\end{array}$ & Sokoto Group & Marine \\
\hline MAASTRICHTIAN & $\begin{array}{l}\text {-Unconformity }----- \\
\text { Dukamaje Formation } \\
\text { Wurno Formation } \\
\text { Taloka Formation } \\
\text { - Unconformity --_-- }\end{array}$ & Rima Group & $\begin{array}{l}\text { Brackish water with } \\
\text { Brief dukamaje } \\
\text { Formation Marine } \\
\text {-intercalation }\end{array}$ \\
\hline $\begin{array}{l}\text { LOWERMOST } \\
\text { CRETACEOUS OR } \\
\text { OLDER }\end{array}$ & $\begin{array}{l}\text { Illo and Gundumi } \\
\text { Formation }\end{array}$ & "Continental Interealaire" & Continental \\
\hline PRECAMBRIAN & \multicolumn{3}{|c|}{ ISEMENT COMPLEX } \\
\hline
\end{tabular}

\subsection{The Paleocene}

The Formation comprises parallel bedded, tabular mudstones, muddy siltstones and fine-grained sandstones. In north-western Nigeria the Sokoto Group is divided into: a lower Dange formation which is a $10 \mathrm{~m}$ gypsiferous, greenish-grey paper shale with abundant Paleocene vertebrates and arenaceous foraminifera and a middle Kalambaina Formation comprising a $10 \mathrm{~m}$ thick fossiliferous marly limestone with shallow, warm-water Tethyan Late Paleocene benthonic foraminifera, and c) an upper $2 \mathrm{~m}$ greenish-grey paper shale at the top of the Kalambaina Formation with an impoverished arenaceous assemblage. The latter unit was referred to as the Gamba Formation by Kogbe (1973).

\subsubsection{Post-Paleocene Age}

The continental deposits of the Gwandu formation disconformably overlie the upper Paleocene marine beds in the Sokoto Basin.

\subsection{Lithostratigraphic Description}

The borehole has a depth of $100.7 \mathrm{~m}$ divided into three distinct lithostratigraphic units (Table 1) 
a) The shales which are fossiliferous with interbedding phosphate nodules; shaly lime stones with a thin layer of limestone interbedding are also present. Some of the shales are also fissile.

b) The middle limestone unit;

c) The upper mudstone unit: This unit of the borehole section belongs to the Gwandu Formation. The unit is about $14.5 \mathrm{~m}$ thick.

\subsection{Geology of the Study Area}

Three different types of formations were encountered during the fieldwork in the study area and are explained in order of their field relationship. Petrographic examination of limestone in Kalambaina Formation (found in the study area) in hand specimen and thin section was made. The Shale in Dange Formation was washed and examined in the laboratory for paleontological analysis. The three different Formations are; Kalambaina formation, Dange Formation and Wurno formation (Yunusa, 2018; Kankara, 2011) Note: Kalambaina and Dange Formations belongs to Paleocene deposits (Sokoto Group) and Wurno Formation belong to Maastritchian deposit (Rima Group) (Table 1)

\subsection{The Kalambaina Formation}

The type section of Kalambaina formation is exposed in the study area. Kalambaina Formation is Paleocene deposit (marine in nature) and belongs to Sokoto Group. Kalambaina Formation is found in the North, southwest and of the study area. It consists of marine yellowish, clayey limestone and shale. Petrographic studies of the Kalambaina limestone in the study area reveals that the limestone is mud supported and consists of carbonate rocks including bioclastic wackstone and Algae wackstone. The carbonate rocks in the type section have been diagenetically altered to varying degrees ranging from early to late diagenesis due to the presence of spary calcite that indicates the degree of diagenesis (Yunusa, 2018).

\subsubsection{Field Occurrences}

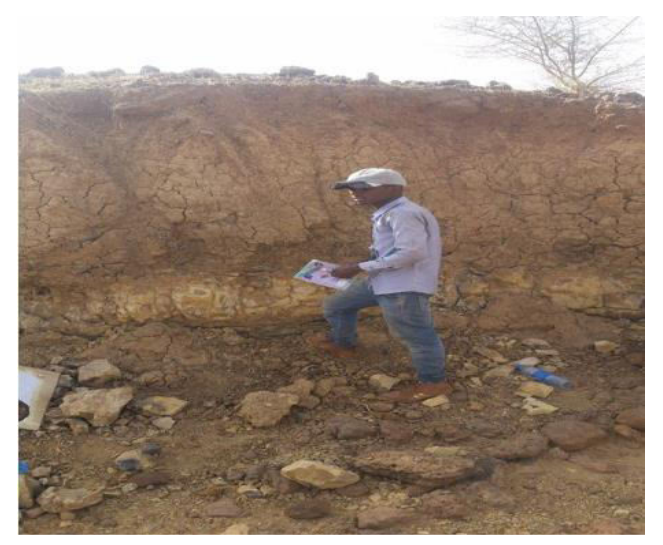

Fig. 2: Part of Lithostratigraphic log of Dange Formation
The Kalambaina Formation observed in the study area consists of a white marine, clayey limestone and shale. The Formation is rich in invertebrate fossils, mainly corals, gastropods and echinoderms. The thickness of the Formation within the study area is quite variable, because of the subsurface dissolution of the limestone (Figure 1).

\subsubsection{Local Stratigraphic Setting}

The exposed section in the study area measured $3.6 \mathrm{~m}$. The section is divisible into two major parts (lower and upper parts). The base is not completely seen. The lower part consists of a clayey, nodular white fossiliferous limestone bed of about $0.6 \mathrm{~m}$ in thickness. The upper part of the section consists of limestone about $2.4 \mathrm{~m}$ in thickness that is white-yellowish in colour. Molds of gastropods, bivalves and brachiopods were observed in this be. Overlies it is Shale that is phosphatized, grey in the colour of about $0.4 \mathrm{~m}$ in thickness (Figure 2) Clastic sediments were also observed in these sediments. A $0.2 \mathrm{~m}$ thick brownish-red bioturbatedoolithic ironstone bed overlies the shale unit. Above the bioturbatedoolitic ironstone is a lateritized topsoil overburden.

\subsection{Dange Formation}

Dange Formation belongs to the Sokoto Group and has Paleocene deposits that are marine nature. The Formation is found in the Northeast and South west of the study area. It consists of Ostracods, Foraminifera and concordant from the paleontological analysis done in the laboratory. Dange formation was found in the northeast and southwest of the study area. It has a yellowish - brown limestone interbedded within the Shale near the base which is indurated. The shale is grey and consists of randomly disseminated phosphate and gypsum within it. The outcrops of Dange Formation have structures like mud cracks, bioturbation, bedding and laminations. The shale of Dangewas subjected to paleontological analysis where foraminifera, ostracods and conodont were observed and studied under a binocular microscope (Figure 3).

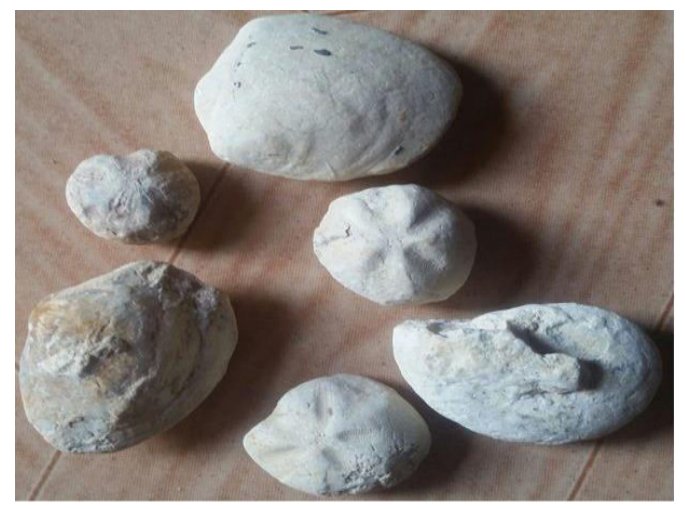

Fig. 3: Macrofossils collected at the upper section of the limestone, Kalambaina Formation 


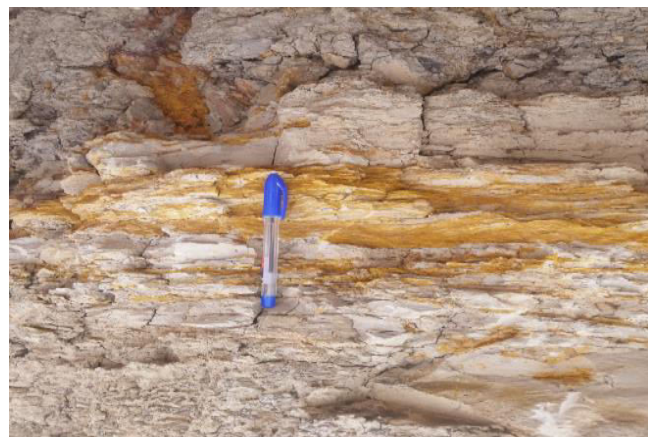

Fig. 4: Outcrop of Dange shale showing bedding and stratification ( $\mathrm{N} 13^{\circ} 38^{\prime} 05.7^{\prime \prime} / \mathrm{E}^{\circ} 5^{\circ} 38^{\prime} 31.2^{\prime \prime}$ elevation of $355 \mathrm{~m})$

\subsubsection{Field Occurrences}

Figure 4 shows the shale outcrop (Dange Formation) observed in the study area, which is grey and slightly indurated shale. Also consists of clay shales within the bands of interbedded yellowish - brownish limestone near the base. The shales include bands of fibrous gypsum and numerous irregular phosphatic nodules, which were probably, derived from the abundant vertebrate fossils remains in Formation. It has no bone bed, although it is richly fossiliferous are not concentrated at in a particular horizon, but occur randomly throughout the formation.

\subsubsection{Local Stratigraphic Settings}

The upper part of the section consists of about $4 \mathrm{~m}$ thick shale sediments. This shale is phosphatized and consists of very thin disseminated gypsum and dark carbonaceous materials. A high percentage of clastic materials was also observed in these sediments. A $2 \mathrm{~m}$ yellowish -brownish limestone is intercalated within the shale near its base and some part of this limestone is dark in coloration. A $0.5 \mathrm{~m}$ thick brownish-red bioturbatedoolitic ironstone bed overlies the shale unit. Above the bioturbatedooilitic ironstone is a lateritized topsoil overburden.

\subsection{Economic Geology}

The most important economic minerals in the mapped area are the industrial minerals consisting of clays/shale, lateritic ironstones, limestone, phosphate and gypsum.

\subsection{Clay Deposits}

Yunusa (2018) observed that the clay deposits in the mapped area are so abundant. A section of clay is found in the Gidan Gado, Kirekafada and Kumaji villages. It could however be possible to exploit most of the Kumaji and whereas the clays or shales of the Kumaji and Gidan Gado (Dange shale) of sediments are already being utilized in



Fig 5: An outcrop of Wurno Formation in the study area showing load cast, bioturbation

the Sokoto Cement Factory. Also, the clay found in the mapped area is used by the citizens in making building bricks.

\subsection{Laterite and Iron Stones}

Kankara (2011) observed the Laterites or lateritic ironstone deserve some consideration because they occur extensively. The ferruginous sandstones have a wide occurrence within the grits and contain a notable proportion of iron ore, as is evident in the slang heaps from local smelting. Occurrence as capping which is more widespread than the interbedded type may be interpreted as having formed by the decomposition of the rocks, that is as insoluble products of weathering. This offers a possible mode of formation, as clays are poorly permeable by their position in the stratigraphic sequence; they occupy the flat summit of the topographically high areas, where they are well exposed to the atmosphere. Lateritic ironstones are used by the citizens for construction purposes, filling of eroded surfaces and embankment.

\subsection{Limestone}

The limestone found in the study area is of Kalambaina formation which was investigated by the Geological Survey of Nigeria (Jones, 1948). The limestone in the mapped area, is at present can be exploited by the cement company of Northern Nigeria (Figures 6 and 7)

\subsection{Phosphate}

The phosphate observed in the study area was randomly disseminated within many outcrops of Dange shales and some of the siltstone of Wurno Formation (Figure 5). The phosphate found in the study area can be used to make calcium phosphate nutritional supplements for animals. Pure phosphorus is used to make chemicals for use in industry (Figure 6). The most important use of phosphate rock, though, is in the production of phosphate fertilizers for agriculture. 

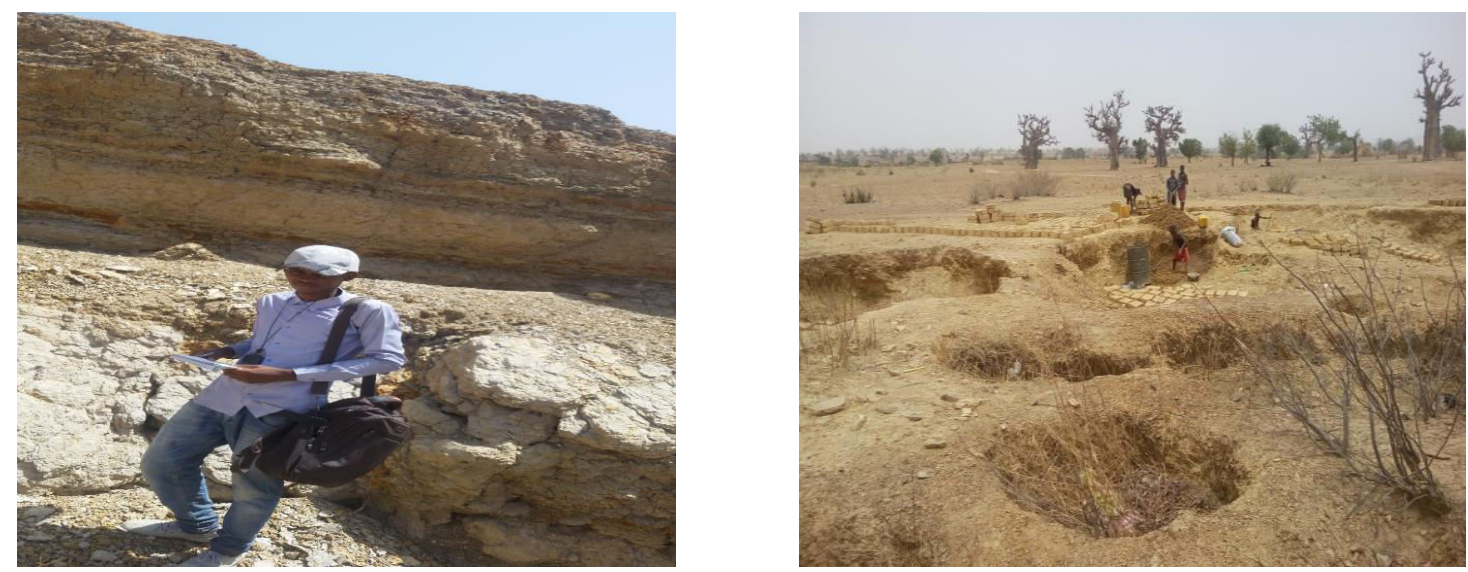

Fig. 6 and 7: Lateritic ironstone in the study area $\left(\mathrm{N} 13^{\circ} 39^{\prime} 25.2^{\prime \prime} / \mathrm{E} 05^{\circ} 39^{\prime} 32.3^{\prime \prime}\right.$ elevation $\left.331 \mathrm{~m}\right)$

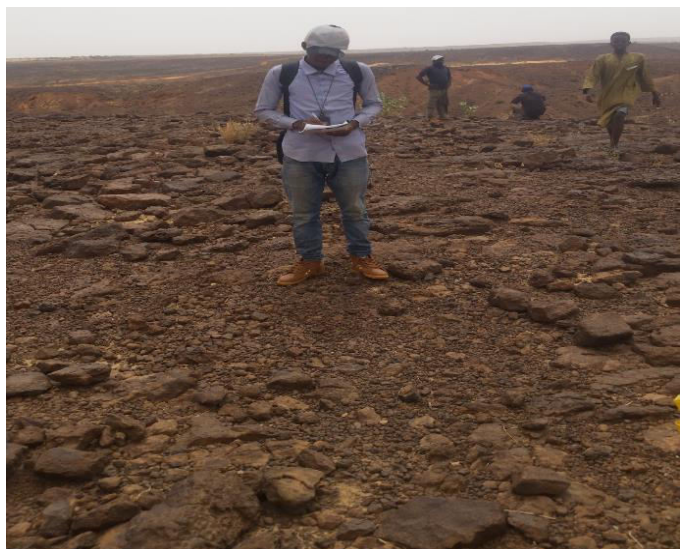

Fig. 8: Outcrop of kumaji shale $\mathrm{N}^{\circ} 33^{\prime} 29.1^{\prime \prime} / \mathrm{E} \mathbf{0 5}^{\circ}$ 41' 41.0"')

\subsection{Gypsum}

The gypsum observed in the study area was disseminated within the Dange shale, siltstone of Wurno Formation and unconformities between the Dange and Wurno Formations. The Gypsum found in the study area has so many important which include; manufacture of wallboard, cement, plaster of Paris, soil conditioning, and a hardening retarder in Portland cement.

\section{Discussion}

The results of the analyses provide that more mineral deposits can be sourced from the outcrops. Apart from these deposits, others occur in many areas of north western Nigeria, which have equally high economic values that can be chased by the government at all levels and local miners. In view of this, the government should encourage more researches. Geological and topographical maps of the solid minerals of the area should be updated and made available and affordable to researchers.

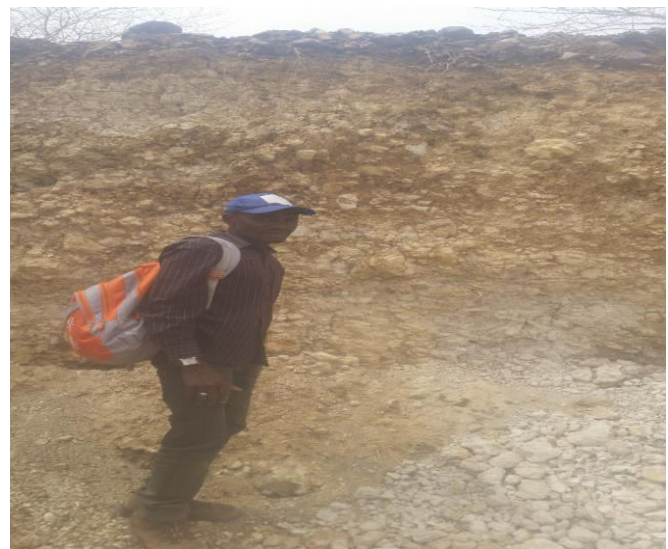

Fig. 9: Building bricks made from clays at $\mathrm{N} 13^{\circ} 37^{\prime} 15.7^{\prime \prime} / \mathrm{E}$ $05^{\circ} 43$ ' 17.8" elevation 299m)

Due to this study, a much more detailed analysis of industrial minerals and the associated rocks should be done, taking into consideration their character variation with depth and lateral changes. Though some of the mineral deposits do not meet the standard for use for some other purposes, more research should be carried out to see if the lithology can be put into any use.

The Federal Government of Nigeria, Sokoto State government and other stakeholders should encourage small-scale miners to invest in the deposits.

\section{Conclusion and Recommendations}

The geological history and nature, economic aspect of rocks and their structural analyses were used in an attempt to explain and interpret the Sokoto Basin and its cycle of sedimentations (of the study area). Categories of sedimentary rocks of economic applications are found in the study area, which must be exploited for economic uses (see figures 6, 8 and 9). This investigation has to some 
extent provided some information which can be employed using geological principles and ground investigations involved with the geotechnical design and engineering of underground projects, evaluation of uncertainties in geological ground conditions, erosion, flooding as well as land slide risk assessment to provide guidance to landslides, slope stability, and seismic investigations.

It is recommended that proper attention should be given to the geology of Gidan Alfarma and its environs to determine the mineralogical viability of the rocks and of the aquifer systems in the area. In doing so, there should be a proper investigation of the geophysical and geochemical survey on the quality of the underground water. The thickness of permeable material over a soft over-burden aquifer is also known so that adequate clean water supply for consumption and irrigation can be provided. This should also provide insight into economic minerals. It is also recommended that these deposits such as clay, shale and lateritic materials be investigated by means of characterization so as to improve their engineering properties for a better and wider application in the provision of more standard housing for the dwellers.

Finally, Government and other Investors should pay proper attention to the development of the study area, because minerals like lateritic ironstones and limestone associated with the study area can really generate revenue to the nation.

\section{References}

[1] Adekeye OA and Akande SO. Mineralogical and geochemical studies of phosphate nodules in the Dange Formation Sokotobasin, northwestern Nigeria. Jour. Mining \&Geol200440(2):101-106.

[2] Ajibade AC and Wright JB. Structural relationship in the schist belt of northwestern Nigerian In: Oluyibe, P.O (Ed.) Precambrian Geology of Nigeria - Geological Survey Of Nigeria, Kaduna. 1998;103-109.
[3] Ball E. An example of very consistent brittle deformation over a wide intra continental area: The late Pan - African fracture system of thee Taureg and Nigerian shield. Tectonophysics. 1980;61:363379.

[4] Dunham RJ. Classification of carbonate according to depositional textures. In: Ham, W.E. (Ed.), Classification of Carbonate Rocks. AAPG Memoir. 1962;1:108-121.

[5] Greigert J. Description des formations CretacesetTertiaires du basin de Iullemeden. Mem. Bur. Rech. Geol. Min 1966:36.

[6] Jones B. The sedimentary rock of Sokoto province. Bull. Geol. Survey of Nigeria. 1948;18:1-72.

[7] Kankara IA. Geology of the Northwestern Nigeria. Long Distant Field Trip of 300 Level, Dept. of Geography Students, Umaru Musa Yar'adua University. 2011

[8] Kogbe CA. Geology of the upper cretaceous and tertiary sediments of the Nigerian sector of the Iullemeden Basin (West Africa). Geol. Rdsch. 1973;62:197-211.

[9] Kogbe CA. Geology of South Eastern (Sokoto) sector of Iullemmeden Basin. Bulletin Department of Geology Ahmadu Bello University, Zaria, Nigeria. 1979;2:No. 1

[10] Kogbe CA. Cretaceous and Tertiary of Iullemmeden Basin in Nigeria (West Africa) Cretaceous research. 1981;2:129-186.

[11] Krasheninnikov VA and Trofimov DM. Sravitel' nyyanalizbenthosnykh..foraminifera datskopaleotsenovykhotlozhneniy Mali, oblastitetisa I severozapodny Evropy. Vopr. Micropaleontol. SSSR. 1969;12:108-144.

[12] McCurry P. The geology of the Precambrian to lower palaeozoic rocks of Northern Nigeria - a review in Kogbe , C.A (e.d) geology of Nigeria. Elizabeth pub. Co. Lagos Nigeria: 1976;41-58.

[13] Obaje NG, Wehner H, Scheeder G, et al. Hydrocarbon prospectivity of Nigeria's inland basins: from the viewpoint of organic geochemistry and organic petrology. Am. Assoc. Pet. Geol. Bull. 2004;87:325-353.

[14] Ogezi AEO. Geochemistry and Geochronology of basement rock from North western Nigeria. Unpublished Ph.D Thesis, Leeds University. 1977

[15] Peters S. The marine Maastritchian and paleocene deposits (of North western Nigeria). The Dukamaje Formation and Sokoto Group. Geological Guide to some Nigerian Cretaceous recent lacalities: 7th African micropal. Coll. Ille - Ife, Nigeria. 1976;75-87.

[16] Wright JB, Hastings DA, Jones WB and Williams HR. Geology and Mineral resources of Africa. George Allen and Urwin, London. 1985;90-120.

[17] Yunusa A. Geology of GidanAlfarma Area, Northwestern Nigeria. An unpublished BSc. Project, Dept. of Geology, UsmanuDanfodio University Sokoto. 2018. 